\title{
The Development of Biology Practicum Learning based on Vee Diagram for Reducing Student Cognitive Load
}

\author{
Anna Fitri Hindriana ${ }^{1)}$ \\ ${ }^{1)}$ Universitas Kuningan, Kuningan, Indonesia \\ E-mail:anna_fitri22@yahoo.com
}

\begin{abstract}
Practicum is a process to gain meaningful knowledge through hands on and minds on activity, thusplan is needed in practicum to connect the conceptual side and methodological side. Vee diagram-based Biology practicum learning was arranged to lower cognitive load of student in designing experiment so the practicum activity become meaningful because the students can see the interesting side in both conceptual side and methodological side. The design that being used in this study was educational study and development. Based on the result of this study, it can be informed that there is lowering of student cognitive load, both in extraneous load and germane load, in designing experiment based on vee diagram
\end{abstract}

Keywords: practicum, vee diagram, cognitive load.

\section{Introduction}

Theoretically, practicum is conducted to develop student's potential in comprehending cognitive skill, psychomotor skill and affective skill, but in the practice, practicum experience in most schools cannot provide any meaningful experience for the student, that is because the practicums that commonly done are more into clarifying the concept learned by student. The statement is supported by Supriatno (2013) who stated that the practicum activity generally done deductively with expository model, commonly known as verification or confirmatory. Furthermore, supriatno explained that procedure aspect, generally are guided like activity in cookbook, there is almost no space for student to design or manipulate the variables.

Based on result of the field study conducted by Biology Education post-graduate students at UniversitasKuningan (Kuningan University), it is found that the practice of practicum in schools is only done to complete the theoretic learning in classroom activity, without following the suggestion of curriculum, this means the concept that being developed is not aiming to get essential comprehending of the lesson. This case is proven because no one has ever analyzed the syllabi in designing practicum activity, resulted that most practicums do not match the competence stated in curriculum. Almost all the teachers have not developed student worksheet that corresponding with the concept, they commonly use worksheet that was provided in text books.
II. Theory

The heuristic vee learning can be used to help student in doing practicum, especially in designing experiment. The components of vee diagram help student in constructing and comprehending knowledge so that they understand what is they learn and what it is about after conducting practicum (Alvarez \&Risko, 2007)Thosecomponents, based on Novak and Gowin (1985) are divided into two. Conceptual side and methodological side. Conceptual side includes concepts, principles, theory, and philosophy. Meanwhile methodological side includes record, transformation, interpretation, and knowledge claim.

Cognitive load is defined as the mental load in doing certain task which effects on cognitive processing system. The mental load from the task and the mental effort that are needed to measure task is important dimension of cognitive load, that can be used to measure cognitive load (Pass \& Van Merriënboer, 1993 ; Van Gog \& Pass, 2008). Total cognitive load from working memory consist of three catagories; intrinsic, germane and extraneous (Sweller, 2005; Swelleret al., 1998). Marcus et al.(1996) stated that cognitive load from learning material is affected by the prior knowledge, the teaching process and organization of learning material.

Biology practicum is a course that provides student to design laboratory experiment and also field study. The experiment designed by the student should be able to connect conceptual aspect learned in classroom with methodological aspect learned in laboratory or on field. Experiment is a method where the scientist test natural phenomenon in hope to get new knowledge (Nuryani, 2005). The good experiment 
design should follow logic design to accurately isolate and test specific variable. By learning about fundamental principle behind experiment design, you will be able to apply this principle to your own experiment. No matter what scoop it is, all good experiment operate corresponds with logic principle and deductive frorm science method. All scientist design experiment to answer questions or to solve problems. The next step is writing hypothesis. Hypothesis is potentially right answer for a question or explanation that will be tested. During the experiment, student have to write all the observation that been done. The result of observation is data that you have. Data interpretation means explaining the data itself. Student can do simple comparison or search for tendency of pattern to do data interpretation. In taking conclusion student have to compare the result of data interpretation with the hypothesis they made in the beginning of experiment. Based on the former explanation, the next step is they can decide whether the hypothesis is correct or wrong. The step is called deduce the conclusion.

\section{Method}

This study developedvee diagram-based biology practicum learning based in designing experiment to lower cognitive load of biology teachers. This study used educational research and development model (Borg \& Gall, 2001)

The study of practicum learning based on vee diagram was done at Biology Education Study Program, on postgraduate school in private university in Kuningan, that have good mark in accreditation system. The subject that were involved in trial stage are 20 students who were on the third semester in academic year of 2012-2013. Whereas for implementation stage, involving 36 students who were on third semester in 2014-2015 academic year that were taking biology practicum course.

The Biology Practicum Learning based on Vee diagram that was developed has six stages of learning, which are (a) Information presentation aimed to develop content skill in designing practicum activity in lab or on the field. The presentation of information is conducted by discussing the importance of comprehending the relation between conceptual aspect and methodological aspect in designing experiment, and the development of experiment design should match the the nature of sciencein learning science. (b) Syllabi analysis, aimed to analyze basic competence to elaborate the practice for developing knowledge aspect, procedure or method and also score from the concept that been learned. (c) Experiment design, aimed to implement the result of syllabi analysis into laboratory activity. Vee diagram was used to ease the implementation of syllabi analysis. (d) Experiment design presentation, aimed to present the result of experiment design and get advice from other students. The presentation of design marked as good if it already develop concept based on the nature of science value. (e) Practicum worksheet creation, aimed to develop worksheet that match the real condition. (f) Worksheet practice test, aims to test the practice of the worksheet in laboratory or on the field. In this stage, students had to effectively and efficiently use the time, tools, and material.

The measurement of cognitive load and data analysis is conducted in quantitative and qualitative. All analysis data process, in correlation, use SPSS 20 for windows.

\section{Result and Discussion}

Based on the implementation result of biology practicum learning based on vee diagram in lowering student cognitive load generally use strategy that can develop student positive perception in relating conceptual side and methodological side. The result of implementation gave information as mentioned below:

\section{A. Information presentation stage.}

In this stage student were given the explanation about how to relate conceptual side to methodological side and the importance of the match between conceptual side and methodological side in conducting practicum at schools. In this stage also, the student were asked to analyze the match of concept and method on worksheet that commonly used in schools. The result of student analysis on the worksheet that commonly used by schools showed that there were many mismatch between basic competence in syllabi both from KTSP curriculum and 2013 curriculum with the practice of curriculum. The next strategy was after students analyzed the worksheet, they were asked to reconstruct the worksheet based on basic competence and science value. In this stage, students started to be keen for mistakes in worksheet that commonly used in schools, for example there was a worksheet about cell that aimed to do practicum that differentiate prokaryote cell and eukaryote cell, but in observation session the observation only differentiate the animal cell and plant cell. This is clearly showed that worksheet has not able to facilitate student to differentiate the two types of cells, because the observation only covered the observation ofeukaryote cell.

\section{B. Syllabi analysis stage}

In this stage the lectures gave instruction to identify the match of basic competence with the nature of sciencethat would be developed during the practicum. Students did discussion about what basic competence they going to choose and what skill will be improved during the practicum., that later will be formulated into operational verb that will be derived into three components of science value; cognitive, psychomotor, and affective that will be develop during the practicum. The need to emphasize on the nature of sciencewhile analyzing syllabi is because almost all worksheet used in school never touch the science value. This reality make the practicum activity meaningless. The result of practicum only abut theory confirmation and tend to strengthening just the cognitive side. Student were never 
expected to use their science process skill during the practicum. The students only asked to collect data but the process of collecting data is not being noticed, for example how the student do the process of observation, data interpretation, classification etc. The affective aspect also rarely noticed during the practicum, thus the knowledge gained by students could not give any experience to apply the practicum result in their daily lives. By analyzing syllabi, the student will comprehend how to lower the basic competence on the nature of sciencethat can be done during the practicum.

\section{Experiment design stage}

In this stage the lecturer gave instruction on how to designing experiment using vee diagram, where the experiment designshould match with the nature of sciencethey had made beforehand. The students decide: 1) conceptual side that will be formulated into questions, theories, principles, concept, hypothesis, variables and conduction. 2) Methodological side that will be decided are the record, data transformation knowledge claim and value claim.

While designing the experiment, student can relate conceptual side and methodology side that will be developed during the practicum. The conceptual side was formulated when designing the experiment has enabled student to do the practicum and observe or identified the practicum result, thus student can collect the result data from practicum to be transformed afterwards. Data transformation was designed in vee diagram has been able to facilitate student to interpret the result data from practicum, thus the student can evaluate whether the practicum has matched the objective of practicum and theory got by students.

\section{Experiment Design Presentation Stage}

In this stage students are asked to present their vee diagram-based experiment design. Based on the presentation it can be informed that the students were 1) facing hardship in differentiating between theory, concept and principle that have to be formulated in vee diagram, this would impede the variable decision for practicum, 2) facing hardship in recording to ease interpretation of practicum result data, most of students had not inputted the quality of observation result and standard indicator for quality and quantity of practicum result., 3) facing hardship in claiming the score, especially the ones that related to daily lives. Those hardships can be overcame by brain storming method, thus the students could get advises from lecturers and their friends.

\section{E.Practicum Worksheet making process stage}

In this stage students made worksheet based on the arrangement standard developed by depdiknas (2013) (ministry of cultures and education). The developed worksheet should contain the name of schools, subject name, class, semester, learning material, basic competence, indicator, objective of practicum, tools and material needed, procedure, observation result and data analysis.

\section{F. Worksheet conduction test stage}

In this stage students tried to apply their worksheets in laboratory, where the practicums were conducted by peer teaching, based on the analysis, $90 \%$ of worksheets could be conducted within the planned time, which was 60 minutes.

Integration between the conceptual side and methodological side in designing experiment using vee diagram gave positive feedback for student thinking process. Especially in their effort to comprehend the conceptual side that have to be connected to methodological side. The positive feedback depended to the learning strategy used in the biology practicum learning based on vee diagram, which are (a) The learning process was conducted contextually, thus the students were easier to comprehend the concept that was learned, because it always related to the problem happened in the practicums at their own schools. (b) Contextual learning enable the positive behavior and perception on the students, this showed theinvolve of student in discussion and giving argumentation in analyze methodological side and conceptual side when designing the experiment. (c) Identification on the focus of the question that match with the phenomenon or object that was going to be observed helped student in formulating theory, and basic concept. (d) Ability to formulate basic concept affected on the increase of skill in deciding the treatment that will be observed. (e) Syllabi analysis related to the nature of science helped students in deciding the knowledge and value that will be developed during the practicum, therefore the conduction of practicum related to the demand of curriculum that emphasized on the balance between hard skill and soft skill.

Measurement of Experiment Designing Skill.

Learning strategy that was developed in biology practicum course was proven could lowering germane load in designing experiment. The result can be observed based on the experiment designing skill presented on the table 1 .

Table 1. Experiment designing skill

\begin{tabular}{|l|c|}
\hline $\begin{array}{c}\text { Indicator of } \\
\text { Experiment designing } \\
\text { skill }\end{array}$ & Score \\
\hline Focus of questions & 3.2 \\
\hline Theory/concept/principle & 3.4 \\
\hline Conduction & 3.4 \\
\hline Recording process & 3.3 \\
\hline Knowledge claim & 3.1 \\
\hline Score claim & 2.8 \\
\hline Average & 3.17 \\
\hline
\end{tabular}

Based on 1 Table, it can be explained that the skill of students in designing experiment has been good because they got 3.7 from the scale of 4 . The highest students' skills lie on formulating theory/basic concept and deciding activity in practicum. This shows that students are able to relate the conceptual side and methodological side in designing 
experiment. The lowest student's skill lies on the score claiming from the result of the practicum. The low score on the score claiming indicators shows that the students are not familiar with relating practicum score with development of attitude in making decision that is beneficial in daily basis.

In designing experiment student has able to (a) Formulating the focus of question which is related to basic concept in practicum. (b) Formulating theory and basic concept that relevant with the proposed method, hypothesis and variable. (c) Deciding activity that will be done by students and consistent with the focus of the question and the record of observation. (d) Formulating questions related to the gain of knowledge based on the result of practicum, thus student are expected to get facts from the object or phenomenon to strengthen the understanding of concept they learned.

\section{Measurement of mental effort in designing experiment}

The measurement of student cognitive load when receiving information (extraneous load) in this study aims to know the student cognitive load from the application of vee diagram-based biology practicum learning. Student cognitive activity on the application of vee diagram - based biology practicum learning is the student mental effort in constructing cognitive scheme to comprehend experiment design. In this study, students' mental effort is categorized as low if the student feel at ease in formulating the focus of question, deciding theory and basic concept, deciding the conduction of practicum, recording the result of practicum, deciding the knowledge claim, and deciding score claim that should be gained by the students in designing experiment. Low mental effort show the decreasing of extraneous load.

Learning strategy that is developed in biology practicum learning was proven can lowering extraneous load in designing experiment, this is result of mental effort in designing experiment is presented on the table 2 .

Table 2. The mental effort in designing experiment

\begin{tabular}{|l|l|}
\hline $\begin{array}{c}\text { Experiment designing } \\
\text { skill indicators }\end{array}$ & Score \\
\hline Focus of questions & 2.75 \\
\hline Theory/concept/principle & 2.8 \\
\hline Conduction & 2.8 \\
\hline Recording process & 2.6 \\
\hline Knowledge claim & 2.6 \\
\hline Score claim & 3.2 \\
\hline Average & 2.76 \\
\hline
\end{tabular}

Based on table 2 it can be described that students' mental effort in designing experiment has been easy enough, this is shown by the average of students' mental effort that is 2.76 out of scale of 5 . The lowest students' mental efforts lie on the indicator of recording practicum result and claiming knowledge. This shows that students found it easier to understanding the methodological side in designing experiment, but the mental effort was supported by the students' skill in formulating focus of the question, theory and basic concept thus it can be informed that the lowest mental effort in deciding the methodological side was supported by the skill in deciding conceptual side. The highest students' mental effort lied on claiming score indicator or the score gained from the result of practicum. This high effort of students in score claiming showed that they found it hard to relate the result of practicum with the development of attitude that beneficial in daily basis.

The Relation between Mental Effort and Experiment Designing Skill.

Students' extraneous load in designing experiment in this study shows how vee diagram-based biology practicum learning can facilitate student in designing experiment, while the designing experiment skill (germane load) in this study shows students' skill in transferring knowledge from long term memory as the result of vee diagram-based biology practicum learning. The two cognitive load are related to each other. To figure out the relation between the two cognitive loads. The analysis using correlational test was done.

Base on the relation between two cognitive load showed significant correlation $\mathrm{p}=0.00 *<0.01$. negative correlation between extraneous load and germane load showed that the lower students' mental effort in understanding information for integrating conceptual side and methodological side, the higher students' skill in designing experiment. Coefficient determinant between extraneous load on germane loadis 0.83 . This showed that $83 \%$ of experiment designing skill was effected by students' mental effort caused by biology practicum that was being developed. Students who got low experiment designing score had high mental effort, whereas the students who get high experiment designing score had low mental effort.

Mental effort in designing experiment in this study was used to measure extraneous load, which is the load cause by learning design and organization of learning material. Vee diagram-based biology practicum learning in this study used constructivism approach using several strategies in delivering learning material. The strategies used in this study were emphasizing on. First, the importance of learning condition, second, the importance of prior knowledge in learning process, third, help understanding information and how the information were used.

Students' extraneous load in this study showed score of 2.76. this showed that the strategies that were being used in 
vee diagram - based biology curriculum learning put student at ease in processing information about relation between conceptual side and methodological side in working memory and construct the cognitive scheme.

The lowering mental skill could be retained on the next learning stage, because those three stages use strategy that facilitate student to assimilate information on knowledge that already have cognitive structure. By assimilating the information, student could widen and modify the relation between concept, thus can ease students in analyzing information. The lowering in mental effort was also proven by responds from students. Students tended to state strongly agree on the learning process because they already had positive perspective on the learning process. This can be proven when they were assigned to design experiment, students tested their designs as material for presentation and did the worksheet that has been designed well.

\section{CONCLUSION}

Based on the study about development of vee-diagram based biology practicum learning, it can be conclude that the learning has six stages of learning, there are information presentation, syllabi analyze, experiment designing, practicum worksheet making process, and worksheet conduction test have been alternative to relate conceptual side and methodological side in designing experiment with low cognitive load. The low cognitive load of students when relate conceptual side with methodological side in designing experiment is because of the learning process emphasized on the creation of conducive learning condition, develop thinking potential, contextual information packaging, and conduct cooperative learning.

The result of this study showed that experiment designing skill is categorized as good with average score 3.17. Students mental effort in designing experiment is categorized low (2.76). students' mental effort in designing experiment has proven to effect experiment designing skill. The correlation between intrinsic germane load on germane load was negative correlated. This study result showed that low mental effort ease student in designing experiment. Thus, the application of learning that was developed could increase thinking skill, facilitate student to construct cognitive scheme that enable them to gain holistic knowledge through the relation between conceptual material that being learned with relevant study field, and also facilitate the use of several cognitive process that emphasize on thinking skill, and overcome the hardship of cognitive task faced by students caused by cognitive capacity that different for each students.

\section{REFERENCES}

[1] Afamasaga-Fuata'i, K..An Undergraduate Student's Understanding Of Differential Equations Through Concept Maps AndVeeDiagrams.
Proc. of the First Int. Conference on Concept Mapping Pamplona, Spain.2004

[2] Afamasaga-Fuata'i, K. Secondary Pre-service Teachers' Use of Vee Diagrams to Analyse Problems and Illustrate Multiple Solutions. MathematicsTeacher Education and Development. Vol. 10. (15-29). 2009

[3] Borg,W.R. \&Gall,M.D.,Educational Research : An Introduction. New York: Longman. 2003

[4] Brookhart,S.M.,Assess Higher Order Thinking Skill in Your Classroom, Virginia USA : ASCD. 2010

[5] Callais, G.J.,TheVee Diagram as a Problem Solving Strategy: Content Area Reading/Writing Implications. National Forum Teacher Education Journal .Vol 19,(3), 1-8.2009

[6] Creswell,J.W., Educational Research, Singapore, Canada, Japan, Australia, North Asia, Malaysia, Mexico, New Jersey : Pearson Education,Ltd. 2008

[7] Dahar,R.W., Teori-teoriBelajar,Jakarta : Erlangga.1989

[8] DeLeew.K.L.,Mayer.R.G., "A Comparison of Three Measures of Cognitive Load: Evidence for Separable Measures of Intrinsic, Extraneous, and Germane Load" . Journal of Education Psychology.100, (1), 1223-1234. 2008

[9] Feldon.D.F,Timmerman.B.G.,Stove.K.A,,"Translating Expertise Into Effective Instruction: The Impacts of Cognitive Task Analysis (CTA) on Lab Report Quality and Student Retention in the Biological Sciences". Journal of Research Science Teaching.(1-21)2009

[10] Fogarty,R., How To Integrate The Curricula, Illionis, Skylight Publishing.Inc. 1991

[11] Gall,M.D.,Gall,J.P.,Borg,W.R, Educational Research, Boston,New York, San Francisco:Pearson education Inc.2003

[12] Glyselinch.V., Janet.E.,Dubois.V., "The Role of Working Memory Components in Multimedia Comprehension". Applied Cognitive Psychology. (353-374). 2008

[13] Haslam.C.Y.,Joseph.R., "Investigating the Use of Integreted Instructions to Reduce the Cognitive Load Associated with Doing Practical Work in Secondary School Science". International Journal of Science Education. 32, (14), 1943-1958. 2010

[14] King,F.D.,Gordon.L, Rohani.F, Assessment \& Evaluation Higher Order Thinking Skills, 1997 [0n line], available : http//www.

[15] Lazear.D,,Higher Order Thinking, Chicago : Zephyr Press. 2004

[16] Lee.H.,Plass.L.,Hormer.B.D., "Optimizing Cognitive Load for Learning From Computer-Based Science Simulations" Journal of Educational Psycology.98, (4), 902-913. 2006

[17] Leutner.D.,Leopold.C., Sumfleth.E.,"'Cognitive load and science text comprehension: Effects of drawing and mentally imagining text content. ELSIEVER. 284-289. 2009

[18] Marzano,R.J., A Different Kind of Classroom, Teaching with Dimension of Learning, Alexandria, Association for Supervision and Curriculum Development. 1992

[19] Mihalca.L.,Salden,R.C.M.,Lurbalam.G.,Pass.F., Miclea.M, "Effectiveness of cognitive-load based adaptive instruction in genetics education".ELSIEVER. 82-88. 2010

[20] Moreno.R., "Decreasing Cognitive Load for Novice Students: Effects of Explanatory versus Corrective Feedback in Discovery-Based Multimedia". Insrtuctional Science. 32,99-113.2006

[21] Moreno.R.,Valdoz.A."Cognitive Load and Learning Effects of Having Students Organize Pictures and Words in Multimedia Environments: The Role of Student Interactivity and Feedback". ETR\&D.53,(3), 35-45. 2007

[22] NRC.,National Science Education Standards. Washington DC : National Academic Press. 1996

[23] NSTA \& AETS, Standards for Science Teacher Preparation. 2000

[24] Ormrod.J.E.,PsikologiPendidikan, Jakarta : Erlangga. 2008

[25] Scharfenberg.F.J.,Bogner.F.X., "Instructional Efficiency of Changing Cognitive load in an Out - of-School Laboratory" ". International Journal of Science Education. 37, (13), 1678-168. 2010 